\title{
Adaptasi Academic Motivation Scale (AMS) versi Bahasa Indonesia
}

\author{
Ramadhan Dwi Marvianto ${ }^{1} \mathcal{E}$ Wahyu Widhiarso ${ }^{2}$ \\ Fakultas Psikologi Universitas Gadjah Mada
}

\begin{abstract}
This study aims to adapt the Academic Motivation Scale (AMS) into Indonesian language. Data collection using online survey on 617 high school students in Yogyakarta. The analyzed property includes discrimination indices, mean, and standard deviation for item level. At test level, the analyzed property are validity and reliability. Procedure of adaptation performed following adequate adaptation guidelines. Findings on the psychometric property evaluation show adapted AMS has satisfactory discriminating indices, mean, and standard deviation of items. At the test level, Adapted AMS has reliability values ranging from 0.73 to 0.90. Contruct validity test shows satisfactory results. This is seen from the results of interdimensional correlations that show a simple pattern as in research conducted by the original scale's maker. Thus, Indonesian version of AMS has satisfactory construct validity and produces reliable scores, so it can be used.
\end{abstract}

Keywords: academic motivation scale; adaptation of psychological testing; motivation; psychometric evaluation.

Abstrak. Penelitian ini bertujuan untuk mengadaptasi skala Academic Motivation Scale (AMS) ke dalam bahasa Indonesia. Pengambilan data menggunakan survei daring pada 617 siswa SMA Negeri di Kota Yogyakarta. Properti yang dianalisis meliputi daya diskriminasi butir, rerata butir, dan standar deviasi butir untuk properti psikometris tingkat butir. Pada tingkat tes, properti yang dianalisis ialah validitas dan reliabilitas. Prosedur adaptasi yang dilakukan mengikuti pedoman adaptasi yang cukup adekuat. Temuan dalam evaluasi properti psikometris menunjukkan skala hasil adaptasi AMS ini memiliki daya diskriminasi, rerata, dan standar deviasi butir yang memuaskan. Pada properti level tes, skala ini telah memiliki nilai reliabilitas yang berkisar $0,73-0,90$. Uji validitas konstrak menunjukkan hasil yang memuaskan. Hal ini dilihat dari hasil korelasi antar dimensi yang menunjukkan pola sederhana seperti pada penelitian yang dilakukan oleh pembuat skala aslinya. Dengan demikian, skala AMS hasil versi bahasa Indonesia memiliki validitas konstrak yang memuaskan dan menghasilkan skor yang reliabel sehingga sudah dapat digunakan.

Kata kunci: academic motivation scale; adaptasi alat ukur psikologis; alat ukur motivasi; motivasi; evaluasi properti psikometris

Motivasi memiliki andil yang besar dalam dunia pendidikan. Banyak penelitian mengemukakan bahwa motivasi berhubungan erat dengan prestasi akademik (Facturahman \& Cholik, 2014; Jatmiko,
2015; Sikhwari, 2014; Ulfah, Santoso, \& Utaya, 2016). Hubungan yang terbentuk menunjukkan semakin siswa memiliki motivasi tinggi untuk bersekolah maka semakin tinggi prestasi akademik yang

\footnotetext{
${ }^{1}$ Korespondensi mengenai isi artikel ini dapat dilakukan melalui marvianto.ramadhandwi@gmail.com

2 atau melalui wahyu psy@ugm.ac.id 
mereka dapat. Tingginya prestasi akademik menjadi salah satu indikator keberhasilan siswa dalam pendidikan. Dengan demikian, mengetahui motivasi siswa dalam bersekolah menjadi hal yang penting untuk mendukung keberhasilan siswa.

Untuk mengetahui motivasi siswa, perlu dilakukan sebuah pengukuran mengenai motivasi. Pengukuran yang dilakukan harus valid dan reliabel. Pengukuran yang valid dan reliabel bisa didapatkan ketika penyajian alat ukur dilakukan secara terstandar dan alat ukur memiliki properti psikometris yang memuaskan (Azwar, 2015, 2017).

Sejauh ini, pengukuran motivasi bersekolah menggunakan alat ukur yang beragam. Alat ukur tersebut dinilai valid dan reliabel dengan melihat beberapa properti psikometris seperti reliabilitas dan daya diskriminasi butir semata. Hal ini tergolong sederhana karena tidak mengikutsertakan properti psikometris lain yang sesungguhnya dapat memberikan gambaran validitas alat ukur.

Selain properti psikometris yang sederhana, kebanyakan alat ukur motivasi termasuk alat ukur yang linear. Alat ukur yang linear ialah alat ukur yang memandang variabel yang mendasarinya sebagai sebuah kontinum dari nilai rendah hingga tinggi (Periantalo, 2016). Hasil pengukuran alat ukur yang linear ini akan mendapati tinggi-rendahnya motivasi siswa untuk bersekolah. Hal ini menjadi sebuah keterbatasan pada pengukuran. Alat ukur tersebut tidak dapat memberikan informasi yang komprehensif mengenai motivasi siswa dalam bersekolah.

Adapun sebuah alat ukur yang memberikan informasi secara komprehensif dan terstandar serta banyak diadaptasi di beberapa negara, alat ukur tersebut ialah Academic Motivation Scale atau disingkat AMS. AMS merupakan alat ukur motivasi yang berlandaskan teori SelfDetermination yang dicetuskan oleh Ryan dan Deci (Vallerand et al., 1992). AMS pertama kali dibuat oleh Vallerand dan kolega dalam bahasa Perancis dengan nama Echele de Motivation en Education (EME) di tahun 1989. Pada tahun 1992, Vallerand melakukan adaptasi EME ke dalam bahasa Inggris sehingga menjadi AMS.

AMS terdiri dari 28 butir pernyataan yang mengukur tujuh jenis motivasi. Ketujuh jenis motivasi tersebut merupakan turunan jenis motivasi yaitu intrinsic motivation, extrinsic motivation dana motivation yang ada pada Self Determination Theory (Vallerand et al., 1992). Tujuh jenis motivasi tersebut intrinsic motivation yang terderivasi menjadi intrinsic motivation to know, intrinsic motivation toward accomplishment, dan intrinsic motivation to experience stimulation, extrinsic motivation yang terderivasi menjadi external regulation, introjected regulation dan identified regulation, serta satu tipe amotivation.

Intrinsic motivation merujuk kepada perilaku individu yang dilakukan untuk kepuasan yang melekat pada diri individu dibanding untuk konsekuensi yang terpisah dari individu (Ryan \& Deci, 2000). Jenis ini diderivasi oleh Vallerand dan koleganya (1992) menjadi tiga jenis intrinsic motivasi. Ketiga jenis tersebut yaitu, (1) Intrinsic motivation to know merujuk kepada sebuah kesenangan dan kepuasan dalam melakukan aktivitas yang mempelajari, mengeksplorasi dan memahami sesuatu yang baru, (2) intrinsic motivation toward accomplished things merujuk kepada kepuasan dan kesenangan individu ketika terlibat pada aktivitas yang berhubungan dengan membuat sesuatu yang baru atau meraih sebuah pencapaian tertentu, dan intrinsic motivation yang terakhir yaitu intrinsic motivation to experience stimulation merujuk kepada segala aktivitas yang membuat individu dapat merasakan sensasi kesenangan dan kepuasan ketika beraktivitas. 
Extrinsic motivation merupakan perilaku yang didasari atas konsekuensi tertentu seperti external reward, penerimaan sosial, menghindari hukuman atau pencapaian dalam prestasi tertentu (Ryan \& Deci, 2017). Ryan dan Deci (2017) menjelaskan derivasi extrinsic motivation didasarkan pada konsep autonomy-control. Autonomy merujuk kepada tingkat di mana perilaku merupakan kehendak dari individu itu sendiri, persetujuan dari diri sendiri untuk melakukan hal tersebut, dan secara penuh ingin terlibat dalam perilaku tersebut. Sedangkan control merujuk kepada perasaan individu di mana mereka merasa tertekan atau terpaksa secara internal maupun eksternal untuk melakukan sesuatu.

Konsep autonomy-control tersebut menjadikan extrinsic motivation menjadi tiga jenis yang membentuk sebuah kontinum. Kontinum paling dasar ialah external regulation yang di dalamnya terdapat control yang paling besar. external regulation ketika perilaku tersebut disebabkan dan dipengaruhi oleh faktor eksternal seperti hadiah atau hukuman (Ryan \& Deci, 2017). Setelah itu terdapat jenis motivasi yang dinamakan Introjected regulation yang di mana telah mengandung sedikit konsep autonomy. Pada jenis ini individu mulai melakukan proses internalisasi sehingga tidak terlalu tergantung pada faktor eksternal (Ryan \& Deci, 2017). Jenis yang paling banyak mengandung konsep autonomy ialah identified regulation. Identified regulation merujuk kepada tingkat internalisasi yang lebih dalam mengenai suatu perilaku, di mana nilai dan pentingnya perilaku dirasakan oleh individu (Ryan \& Deci, 2017).

Karena AMS tergolong komprehensif dalam mengukur motivasi, beberapa penelitian yang mengadaptasi skala ini telah dilakukan. Beberapa penelitian tersebut meliputi penelitian yang dilakukan oleh Alivernini dan Lucidi (2008) mengadaptasi ke bahasa Itali, Barkoukis dan koleganya (2008) mengadaptasi ke bahasa Yunani dan Karaguven (2012) yang mengadaptasi ke bahasa Turki. Hasil ketiga penelitian tersebut menunjukkan bahwa skala AMS hasil adaptasi memiliki reliabilitas dan validitas khususnya validitas konstrak yang memuaskan.

Dengan demikian, penelitian ini bertujuan untuk mengadaptasi AMS ke dalam versi bahasa Indonesia. Pengadaptasian ini nantinya akan menghasilkan alat ukur motivasi yang komprehensif dan teruji baik itu validitas dan reliabilitasnya.

\section{Metode}

\section{Proses Adaptasi Skala AMS}

Proses adaptasi skala AMS ke dalam Bahasa Indonesia mengikuti panduan yang dikemukakan oleh Purwono (2010). Terdapat tiga tahapan dalam proses adaptasi. Pertama, penelaahan konstrak bersama beberapa ahli. Tahap ini dilakukan untuk memastikan konstrak yang ada sesuai dengan konteks budaya yang ada di Indonesia. Tahap kedua ialah penerjemahan yang dilakukan dengan desain forwardtranslation. Penerjemahan dilakukan oleh tim penerjemah yang berisikan mahasiswa yang berkompeten dalam melakukan penerjemahan Inggris-Indonesia dan mahasiswa yang memahami teori.

Skala hasil terjemahan diuji coba pada studi pendahuluan untuk dipastikan seberapa mudah skala tersebut dipahami dan seberapa sesuai respons subjek pada skala tersebut. Studi pendahuluan mengikutsertakan 14 siswa SMA. Siswa diminta merespons seluruh pernyataan dan menilai seberapa mudah setiap butir untuk dipahami. Proses ini menghasilkan skala AMS versi bahasa Indonesia yang mudah dipahami dan sesuai dengan respons yang diharapkan. Tahap ketiga, skala AMS versi bahasa Indonesia diuji secara psikometri 
untuk mendapatkan validitas dan reliabilitasnya. skala yang bersifat multidimensional dengan 7 dimensi. Dengan demikian,

\section{Tabel 1}

Properti psikometris level butir pada masing-masing dimensi

\begin{tabular}{|c|c|c|c|c|c|c|c|}
\hline \multirow{2}{*}{$\begin{array}{c}\text { Properti } \\
\text { Psikometris }\end{array}$} & \multicolumn{7}{|c|}{ Dimensi } \\
\hline & IMTK & IMTA & IMTE & IR & INR & ER & $\mathrm{AMO}$ \\
\hline $\begin{array}{l}\text { Daya } \\
\text { diskriminasi }\end{array}$ & $\begin{array}{c}0,479- \\
0,681\end{array}$ & $\begin{array}{c}0,442- \\
0,582\end{array}$ & $\begin{array}{c}0,367- \\
0,708\end{array}$ & $\begin{array}{c}0,589- \\
0,776\end{array}$ & $\begin{array}{c}0,579- \\
0,672\end{array}$ & $\begin{array}{c}0,611- \\
0,720\end{array}$ & $\begin{array}{c}0,688- \\
0,826\end{array}$ \\
\hline Endorsability & $\begin{array}{c}5,59- \\
5,89 \\
\end{array}$ & $\begin{array}{c}5,07- \\
5,63 \\
\end{array}$ & $\begin{array}{c}4,87- \\
5,33 \\
\end{array}$ & $\begin{array}{c}5,5- \\
5,78 \\
\end{array}$ & $\begin{array}{c}4,84- \\
5,75 \\
\end{array}$ & $\begin{array}{c}5,57- \\
6,32 \\
\end{array}$ & $\begin{array}{c}2,57- \\
3,43 \\
\end{array}$ \\
\hline $\begin{array}{l}\text { Standar } \\
\text { deviasi }\end{array}$ & $\begin{array}{l}0,93- \\
1,143\end{array}$ & $\begin{array}{c}1,066- \\
1,35 \\
\end{array}$ & $\begin{array}{c}1,167- \\
1,509\end{array}$ & $\begin{array}{c}1,077- \\
1,262 \\
\end{array}$ & $\begin{array}{c}1,066- \\
1,49 \\
\end{array}$ & $\begin{array}{c}0,951- \\
1,696 \\
\end{array}$ & $\begin{array}{c}1,562- \\
1,757\end{array}$ \\
\hline $\begin{array}{ll}\text { Keterangan: } \\
\text { IMTK } & \text { :Intrinsic } \\
\text { IMTA } & \text { : Intrinsic } \\
\text { IMTE } & \text { : Intrinsic } \\
I R & : \text { Identified } \\
\text { INR } & \text { :Introjecte } \\
E R & \text { : External } \\
A M O & \text { : Amotivat }\end{array}$ & $\begin{array}{l}\text { lotivation to } \\
\text { lotivation to } \\
\text { lotivation to } \\
\text { legulation } \\
\text { Regulation } \\
\text { gulation } \\
n\end{array}$ & $\begin{array}{l}\text { ow } \\
\text { perience St }\end{array}$ & $\begin{array}{l}\text { things } \\
\text { ulation }\end{array}$ & & & & \\
\hline
\end{tabular}

\section{Subjek Penelitian}

Subjek penelitian ini ialah siswa SMA Negeri di Kota Yogyakarta. Penelitian ini mengikutsertakan 617 siswa (179 laki-laki dan 438 perempuan) yang berada antara kelas $X$ hingga XII. Subjek memiliki usia berkisar antara 14 hingga 18 tahun.

\section{Analisis Data}

Pendekatan klasik dilakukan untuk menganalisis data penelitian ini. Properti psikometris yang akan dianalisis ialah daya diskriminasi butir, endorsability butir, standar deviasi butir dan reliabilitas serta validitas konstrak. Reliabilitas didapatkan melalui konsistensi internal menggunakan formula Cronbach's Alpha. Validitas konstrak diuji melalui korelasi antar dimensi yang akan membentuk pola sederhana.

\section{Hasil}

AMS terdiri dari 28 butir pernyataan. Setiap pernyataan memiliki tujuh pilihan respons. Mulai dari Sangat Tidak Setuju (1) hingga Sangat Setuju (7). Skala AMS merupakan pengujian properti psikometris pada level butir dilakukan berdasarkan dimensi masing-masing. Tabel 1 menunjukkan properti psikometris level butir pada masing-masing dimensi.

\section{Daya Beda Butir}

Daya diskriminasi butir dilihat dari nilai corrected item-total correlation. Nilai di atas 0,3 menunjukkan bahwa butir tersebut memiliki daya diskriminasi yang baik (Azwar, 2015, 2017). Berdasar Tabel 1, seluruh butir pada masing-masing dimensi memiliki nilai di atas 0,3 . Dengan demikian, seluruh butir memiliki daya diskriminasi yang baik.

\section{Endorsability Butir}

Endorsability atau tingkat kesulitan butir dapat dilihat dari nilai rerata (mean) butir. Nilai endorsability yang baik ialah nilai yang mendekati nilai tengah (median) (Berk, 2006). Pada skala yang menggunakan 7 pilihan respons, nilai 4 menjadi nilai tengah. Berdasarkan Tabel 1, hampir seluruh dimensi memiliki endorsability yang 
mendekati nilai 4 kecuali dimensi Amotivation.

\section{Standar Deviasi Butir}

Standar deviasi butir dilihat dari nilai SD pada masing-masing butir. Properti ini menunjukkan seberapa bervariasi respons subjek pada masing-masing butir. Berk (2006) memberikan panduan bahwa semakin besar nilai SD maka semakin bervariasi jawaban subjek terhadap butir tersebut. Berdasar Tabel 1, seluruh butir memiliki nilai SD di atas 1 kecuali satu butir pada dimensi IMTK dan ER yang berkisar 0,9 . Namun demikian, dapat dikatakan variasi respons subjek pada setiap butir tergolong memuaskan. Selain pengujian properti level butir, pengujian properti psikometris level skala juga dilakukan. Adapun properti psikometris yang diuji ialah reliabilitas dan validitas konstrak.

\section{Reliabilitas}

Setiap dimensi pada AMS memilliki nilai reliabilitas masing-masing. Tabel 2 menunjukkan nilai reliabilitas berkisar 0,73 hingga

Tabel 2

Reliabilitas selurth dimensi AMS

\begin{tabular}{|c|c|c|c|c|c|c|c|}
\hline & IMTK & IMTA & IMTE & IR & INR & ER & $\mathrm{AMO}$ \\
\hline $\begin{array}{c}\text { Reliabilitas } \\
\text { Cronbach's Alpha }\end{array}$ & 0.80 & 0,73 & 0,75 & 0,86 & 0,81 & 0,84 & 0,90 \\
\hline \multicolumn{8}{|c|}{ Keterangan: } \\
\hline \multicolumn{8}{|c|}{ : Intrinsic Motivation to Know } \\
\hline \multicolumn{8}{|c|}{ :Intrinsic Motivation toward Accomplish things } \\
\hline \multicolumn{8}{|c|}{ Intrinsic Motivation to Experience Stimulation } \\
\hline \multicolumn{8}{|c|}{ Identified Regulation } \\
\hline \multicolumn{8}{|c|}{ Introjected Regulation } \\
\hline \multicolumn{8}{|c|}{ External Regulation } \\
\hline \multicolumn{8}{|c|}{ : Amotivation } \\
\hline
\end{tabular}

Tabel 3

Korelasi antar dimensi AMS

\begin{tabular}{|c|c|c|c|c|c|c|c|}
\hline Dimensi & IMTK & IMTA & IMTE & IR & INR & ER & $\mathrm{AMO}$ \\
\hline IMTK & 1 & $0,748^{* * *}$ & $0,398^{* * *}$ & $0,292^{\text {:** }}$ & $0,277^{* * *}$ & 0,073 & $-0,311^{* * *}$ \\
\hline IMTA & & 1 & $0,405^{* * *}$ & $0,447^{* *}$ & $0,434^{* * *}$ & $0,235^{* * *}$ & $-0,283^{* *}$ \\
\hline IMTE & & & 1 & $0,086^{*}$ & $0,241^{*}$ & $0,086^{*}$ & $-0,058$ \\
\hline IR & & & & 1 & $0,404^{* * *}$ & $0,437^{* * *}$ & $-0,481^{* * *}$ \\
\hline INR & & & & & 1 & $0,658^{* * *}$ & $-0,198^{* *}$ \\
\hline ER & & & & & & 1 & $-0,161^{* *}$ \\
\hline $\mathrm{AMO}$ & & & & & & & 1 \\
\hline Keterangan: & IMTK & \multicolumn{5}{|c|}{ = Intrinsic Motivation to Know } & \\
\hline & IMTA & \multicolumn{5}{|c|}{$=$ Intrinsic Motivation toward Accomplish } & \\
\hline & IMTE & \multicolumn{5}{|c|}{$=$ Intrinsic Motivation to Experience Stimulation } & \\
\hline & IR & \multicolumn{5}{|c|}{$=$ Identified Regulation } & \\
\hline & INR & \multicolumn{5}{|c|}{$=$ Introjected Regulation } & \\
\hline & $E R$ & \multicolumn{5}{|c|}{$=$ External Regulation } & \\
\hline & $A M O$ & \multirow{2}{*}{\multicolumn{4}{|c|}{$\begin{array}{c}=\text { Amotivation } \\
0.05 \cdot * *=\text { sionifikn }<0.07\end{array}$}} & & \\
\hline & ${ }^{*}=$ signifi & & & & & & \\
\hline
\end{tabular}


0,90 . Nilai tersebut menurut tergolong memuaskan karena melebih nilai minimal yang harus diperoleh, yaitu 0,73 (Azwar, 2015, 2017). Dengan demikian dapat dikatakan seluruh dimensi AMS memiliki nilai yang memuaskan.

\section{Validitas Konstrak}

Validitas konstrak didapat dari hasil korelasi antar dimensinya. Vallerand dan koleganya (1993) menjelaskan bahwa skala AMS memiliki dimensi yang saling berkorelasi dengan membentuk pola sederhana. Pola yang terjadi ialah semakin dekat dimensi yang saling dihubungkan maka semakin tinggi pula korelasinya. Sebaliknya, semakin jauh dimensi yang saling dihubungkan maka semakin rendah korelasinya bahkan dapat membentuk korelasi negatif.

Tabel 3 merangkum seluruh korelasi antar dimensi. Berdasar tabel tersebut, dapat dilihat bahwa hampir seluruh korelasi signifikan. Kecuali korelasi antara IMTK-ER dan IMTE-AMO. Pola yang terbentuk pada seluruh dimensi membentuk pola seperti yang ditemukan oleh Vallerand (1992). Namun demikian, terdapat anomali pada beberapa korelasi yang terjadi.

\section{Diskusi}

Penelitian ini bertujuan untuk melakukan adaptasi Academic Motivation Scale ke dalam versi bahasa Indonesia. Panduan yang dianut untuk melakukan adaptasi diambil dari penjelasan Purwono (2010) mengenai adaptasi alat ukur. Dalam proses adaptasi, pengujian secara psikometrik mengikutsertakan beberapa properti psikometris meliputi daya diskriminasi butir, endorsability butir, standar deviasi butir, reliabilitas dan validitas konstrak.

Temuan pertama menunjukkan bahwa seluruh butir AMS memiliki daya diskriminasi yang baik di setiap dimensi- nya. Daya diskriminasi yang baik menunjukkan bahwa butir tersebut dapat membedakan antara kelompok individu dengan skor tinggi dan kelompok individu dengan skor rendah (Azwar, 2015, 2017; Berk, 2006). Dengan demikian seluruh butir dari AMS versi bahasa Indonesia ini dapat membedakan kelompok individu yang memiliki performa rendah dan tinggi pada variabel motivasi.

Selain daya diskriminasi, endorsability butir atau tingkat kesulitan butir memiliki nilai yang cukup memuaskan. Hal ini didapat dari pedoman yang diberikan oleh Berk (2006), di mana untuk butir yang memiliki 7 pilihan respons, terdapat tiga kategori nilai rerata butir. Endorsability butir yang memiliki nilai berkisar 3-5 tergolong rerata yang sangat baik karena berada dekat dengan nilai tengah respons. Nilai yang berkisar pada 2-3 dan 5-6 tergolong butir yang cukup baik. Sedangkan butir yang memiliki nilai rerata berkisar 1-2 dan 6-7 tergolong butir yang jelek karena terlalu sulit (berkisar 1) dan terlalu mudah (berkisar 6-7). Dengan demikian seluruh butir tergolong memiliki endorsability yang cukup baik/memuaskan.

Ketiga, properti standar deviasi menjelaskan seberapa bervariasi butir direspons oleh subjek (Berk, 2006). Semakin tinggi nilai SD maka semakin bervariasi respons subjek dalam menjawab butir tersebut. Hal ini menunjukkan bahwa butir tersebut tidak membuat mengarahkan subjek untuk memilih jawaban yang sama melainkan membuat subjek dapat merespons butir tersebut secara bervariasi. Maksudnya, respons subjek pada butir tersebut tidak terpusat pada salah satu alternatif respons yang diberikan.

Berk (2006) juga memberikan panduan bahwa semakin besar nilai SD maka semakin bervariasi jawaban subjek terhadap butir tersebut. Untuk butir yang memiliki tujuh pilihan jawaban, Berk (2006) mengelompokkan butir menjadi tiga 
kategori meliputi butir yang jelek, cukup baik dan sangat baik. Butir yang jelek ialah butir yang memiliki SD berkisar 0-9, butir yang cukup baik memiliki nilai SD berkisar 1 -1,9 dan butir yang sangat baik memiliki nilai SD yang lebih besar dari 2 . Berdasarkan klasifikasi tersebut, seluruh butir pada AMS versi bahasa Indonesia tergolong pada nilai SD yang cukup baik. Dengan demikian dapat dikatakan variasi pada setiap butir AMS versi bahasa Indonesia tergolong memuaskan.

Pada properti level tes atau skala, reliabilitas dan validitas merupakan hal yang sangat penting. Validitas yang diuji pada penelitian ini ialah validitas konstrak. Validitas konstrak pada penelitian ini mengambil dari penelitian Vallerand (1993) yang menemukan pola sederhana pada korelasi antar dimensi. Semakin dekat dimensi yang dikorelasikan maka semakin tinggi nilai korelasinya, sebaliknya semakin jauh dimensi yang dikorelasikan maka semakin rendah korelasinya bahkan dapat menjadi korelasi yang negatif. Hasil penelitian ini menunjukkan serupa dengan penelitian Vallerand (1993). Namun demikian, terdapat beberapa anomali.

Anomali yang terjadi ada pada korelasi IMTK-ER dan IMTE-AMO serta beberapa korelasi seperti IMTK - INR, IMTA - INR dan ER - INR. Anomali seperti ini juga terjadi pada penelitian lain yang mengadaptasi AMS. Penelitian pada bahasa Italia dengan konteks siswa sekolah menengah menemukan anomali pada AMO - ER dan ER - INR (Alivernini \& Lucidi, 2008). Penelitian adaptasi AMS pada bahasa Norwegia menemukan anomali pada korelasi IMTA - INR, IMTE ER, dan IR - AMO (Støen Utvær \& Haugan, 2016). Anomali yang terjadi tidak membuat temuan dalam penelitian ini dikatakan tidak membentuk pola. Hal serupa juga terjadi pada penelitian Vallerand tahun 1993 untuk menguji konstrak AMS dan ia menyimpulkan bahwa pola yang terjadi membentuk sebuah pola sederhana (Vallerand et al., 1993).

Nilai negatif pada seluruh korelasi dimensi AMO dengan dimensi lainnya juga merupakan hal yang wajar. Penelitian Vallerand (1993), Alivernini dan Lucidi (2008), Barkouikis dan koleganya (2008), Karaguven (2012) dan Støen Utvær \& Haugan (2016) menemukan hal yang serupa bahwa seluruh korelasi dimensi amotivation dengan dimensi lain bernilai negatif dan membentuk pola yang sederhana, yaitu semakin jauh dimensi yang berhubungan dengan amotivation, maka nilai korelasi negatifnya akan semakin tinggi.

Pada properti reliabilitas, seluruh dimensi skala AMS versi bahasa Indonesia memiliki nilai di atas 0,7. Azwar (2015, 2017) menjelaskan bahwa nilai reliabilitas 0,7 tergolong baik untuk reliabilitas pada skala yang digunakan dengan tujuan melakukan penelitian. Nilai reliabilitas yang berkisar 0,7 hingga 0,8 juga dapat digunakan untuk tujuan penelitian dan tujuan praktik (Furr \& Bacharach, 2013). Dengan demikian, dapat dikatakan bahwa reliabilitas seluruh dimensi pada AMS versi bahasa Indoensia ini tergolong sangat memuaskan dan bisa digunakan untuk tujuan penelitian dan praktik.

\section{Kesimpulan}

Temuan dalam penelitian ini yang berupa properti psikometris level butir dan skala mendukung bahwa skala AMS versi bahasa Indonesia telah diadaptasi dengan baik dan dengan hasil yang memuaskan. Properti psikometris level butir menunjukkan seluruh butir memiliki daya diskriminasi, endorsability butir dan standar deviasi butir yang memuaskan. Sedangkan pada properti psikometris level tes/skala, AMS versi bahasa Indonesia ini memiliki validitas konstrak yang baik karena sesuai dengan konstrak yang mendasarinya dan memiliki 
nilai reliabilitas yang baik. Dengan demikian, skala AMS versi bahasa Indonesia dapat digunakan untuk mengukur motivasi siswa dalam konteks penelitian dan praktik.

Saran

Dalam pengembangannya, perlu dilakukan penelitian lanjutan untuk mendapatkan bukti validitas skala AMS versi bahasa Indonesia. Misal, penelitian selanjutnya dapat melakukan penelitian untuk menguji validitas konstrak menggunakan CFA atau dengan pendekatan lain. Selain itu, penelitian selanjutnya dapat mengambil subjek yang lebih luas agar nantinya skala AMS versi bahasa Indonesia bisa digunakan pada populasi yang lebih luas.

\section{Daftar Pustaka}

Alivernini, F., \& Lucidi, F. (2008). The Academic Motivation Scale (AMS): Factorial structure, invariance, and validity in the Italian context. TPM Testing, Psychometrics, Methodology in Applied Psychology, 15(4), 211-220.

Azwar, S. (2015). Penyusunan skala psikologi (Edisi II). Yogyakarta: Pustaka Pelajar. Azwar, S. (2017). Reliabilitas dan validitas (Edisi 4). Yogyakarta: Pustaka Pelajar. Barkoukis, V., Tsorbatzoudis, H., Grouios, G., \& Sideridis, G. (2008). The assessment of intrinsic and extrinsic motivation and amotivation: Validity and reliability of the Greek version of the Academic Motivation Scale. Assessment in Education: Principles, Policy \& Practice, 15(1), 39-55. doi: 10.1080/09695940701876128

Berk, R. A. (2006). Thirteen strategies to measure college teaching. Virginia: Stylus Publishing.

Facturahman, R., \& Cholik, M. (2014). Hubungan motivasi dengan prestasi belajar pada mata diklat sistem kopling siswa kelas XI di SMK Negeri
3 Surabaya. Jurnal Pendidikan Teknik Mesin, 3(1), 74-80.

Furr, M. R., \& Bacharach, V. R. (2013). Psychometric: An introduction (2nd ed.). Amazon: SAGE Publisher.

Jatmiko. (2015). Hubungan motivasi belajar dengan hasil belajar matematika siswa kelas X SMK Nahdhatul Ulama Pace Nganjuk. Jurnal Math Educator Nusantara, 1(2), 205-213.

Karagüven, M. H. Ü. (2012). The adaptation of Academic Motivation Scale to Turkish. Educational Sciences: Theory and Practice, 12(4), 2611-2618.

Periantalo, J. (2016). Penelitian kuantitatif untuk psikologi. Yogyakarta: Pustaka Pelajar.

Purwono, U. (2010). 50 tahun Himpunan Psikologi Indonesia: Redefinisi psikologi Indonesia dalam keberagaman. In Supratiknya \& T. Susana (Eds.). Jakarta: Himpunan Psikologi Indonesia.

Ryan, R. M., \& Deci, E. L. (2000). Selfdetermination theory and the facilitation of intrinsic motivation, social development, and well-being. American Psychologist Association, 55(1), 68-78. doi: 10.1037/0003-066X.55.1.68

Ryan, R. M., \& Deci, E. L. (2017). Selfdetermination theory. New York: The Guilford Press.

Sikhwari, T. D. (2014). A Study of the relationship between motivation, selfconcept and academic achievement of students at a University in Limpopo Province, South Africa. Jurnal Education and Science, 6(1), 19-25.doi: $\underline{10.1080 / 09751122.2014 .11890113}$

Støen Utvær, B. K., \& Haugan, G. (2016). The academic motivation scale: dimensionality, reliability, and construct validity among vocational students. Nordic Journal of Vocational Education and Training, 6(2), 17-45. doi: 10.3384/njvet.2242-458X.166217

Ulfah, K. R., Santoso, A., \& Utaya, S. (2016). 
Hubungan motivasi dengan hasil belajar IPS. Jurnal Pendidikan, 1(8), 1607-1611. doi: $\underline{10.17977 / j p . v 1 i 8.6678}$ Vallerand, R. ., Pelletier, L., Blais, M., Briere, N., Senecal, C., \& Vallieres, E. (1993). On the assessment of intrinsic, extrinsic, and amotivation in education: Evidence on the concurrent and contrast validity of the academic motivation scale. Educational and Psychological Measurement.
Educational and Psychological Measurement, 53(52), 159-172. doi: $\underline{10.1177 / 0013164493053001018}$

Vallerand, R. J., Pelletier, L. G., Blais, M. R., Hriere, N. M., Senecal, C., \& Vallieres, E. F. (1992). The academic motivational scale: A measure of intrinsic, extrinsic, adn amotivation in education. Educational and Psychological Measurement, 52, 1003-1017. doi: $\underline{10.1177 / 0013164492052004025}$ 